\title{
SOIL MACROFAUNA IN COVER CROPS OF FIGS GROWN UNDER ORGANIC MANAGEMENT
} \author{
Adriana Maria de Aquino ${ }^{2 *}$ \\ ${ }^{l}$ USP/ESALQ - Programa de Pós-Graduação em Ecologia de Agroecossistemas. \\ ${ }^{2}$ Embrapa Agrobiologia, BR 465, km 47 - 23890-000 - Seropédica, RJ - Brasil. \\ *Corresponding author <adriana@cnpab.embrapa.br>
}

Analy de Oliveira Merlim; José Guilherme Marinho Guerra²; Rodrigo Modesto Junqueira²;

\begin{abstract}
Soil fauna plays an important role in organic management through their effects on soil organic decomposition, nutrient mineralization, and amelioration of the soil's physical properties. This work evaluates the density and diversity of the soil macrofauna under types of cover plants in areas cultivated with Ficus carica L. under organic management. The soil macrofauna was collected in $0.25 \times 0.25 \mathrm{~m}$ areas, down to a soil depth of $0.3 \mathrm{~m}$, and at the surface layer. The treatments consisted of bahiagrass living mulch (Paspalum notatum), siratro living mulch (Macroptilium atropurpureum), and bahiagrass mulch. The highest macrofauna density and the lowest diversity were observed in bahiagrass, of which $80 \%$ were represented by ants, thus characterizing the soil under this cover crop as showing the lowest functional diversity and quality.

Key words: Ficus carica L, soil fauna, soil quality indicators
\end{abstract}

\section{MACROFAUNA EDÁFICA SOB COBERTURAS DO SOLO NO CULTIVO DO FIGO SOB MANEJO ORGÂNICO}

\begin{abstract}
RESUMO: A fauna do solo tem papel importante em sistemas orgânicos, através dos seus efeitos na decomposição da matéria orgânica, mineralização de nutrientes e condicionamento físico do solo. Este trabalho avaliou a densidade e a diversidade da macrofauna edáfica sob tipos de cobertura do solo em áreas cultivadas com Ficus carica L. sob manejo orgânico do solo. A macrofauna foi coletada em áreas de 0,25 × 0,25 m e amostraram-se as camadas de material vegetal e solo até a profundidade de 0,3 m, nos meses de março e setembro de 2001. Os tratamentos constaram de cobertura viva com grama batatais (Paspalum notatum), cobertura viva de siratro (Macroptilium atropurpureum) e cobertura morta formada por palha de grama batatais. A mais alta densidade da macrofauna e a mais baixa diversidade foi observada em grama batatais, sendo mais de $80 \%$ dessa fauna de formigas, o que caracteriza o solo sob influência desta cobertura como o de mais baixa diversidade funcional e qualidade, comparado às outras coberturas.

Palavras-chave: Ficus carica L, fauna do solo, indicadores de qualidade do solo
\end{abstract}

\section{INTRODUCTION}

Soil organic management represents a very promising alternative for the sustainable production of foods, satisfying a demand that comes from all sectors of society. The use of legume plants as living mulches for the soil fits well within this context, since it is a technique that contributes toward maintaining soil organic matter and incorporating atmospheric $\mathrm{N}$, in addition to protecting the soil against erosive processes. However, little is known about the impact sustained by the soil fauna as a consequence of the use of these cover plants under organic management.

The soil fauna populations can be markedly affected by soil cover, as the availability of energy associated with the existence of new habitats favorable to colonization increases, thus influencing density and diversity of nearly all groups in this particular fauna (Tian et al., 1999). Both the soil's microorganisms and fauna can modify the physical and chemical properties of the soil (Pankhurst \& Lynch, 1994), and assume an essential role in the soil processes under organic management. This aspect has been considered as one of the key processes for maintaining the structure and fertility of tropical soils (Lavelle et al., 1993).

Among the animals that make up the soil fauna, the edaphic macrofauna comprises the largest invertebrates dwelling in it, with a body length longer than 10 mm (Swift et al., 1979). The community structure of the soil macrofauna can act as an indicator of environmentsoil changes (Lavelle, 1997). Maybe the approach that contributes the most for an understanding of the regulatory ability of the soil fauna in different ecosystems and the expected consequences when one or more groups are excluded consists in analyzing the composition and importance of certain functional groups (Costa, 2002).

The macrofauna has a potential to become a quality indicator, since it is visible to the naked eye, in addi- 
tion to being responsive to management. However, knowledge has to be produced about the groups of organisms that occur under the various types of organic management, their type of response, and the role played by them.

The objective of this work was to evaluate the soil macrofauna community under different soil covers in fig trees growing under organic management, identifying their composition, diversity, and abundance, as a first step toward obtaining bioindicators for these systems in the future.

\section{MATERIAL AND METHODS}

A fig orchard (Ficus carica L.), variety Roxo de Valinhos, was implemented in a Typic Palehumult in March 2000 in an area that belongs to SIPA (Sistema Integrado de Produção Agroeocológica - Agroecological Production Integrated System, Almeida et al., 1999), in the municipality of Seropédica, RJ $\left(43^{\circ} 41^{\prime} 10^{\prime \prime} \mathrm{W}\right.$ and $22^{\circ} 45^{\prime} 30^{\prime \prime} \mathrm{S}$, at $33 \mathrm{~m}$ above sea level), using organic production methods.

The organic production methods refer to those preconized in Instrução Normativa ${ }^{\circ} 07$ (Normative Instruction no. 7), dated 17 May 1999, by Ministério da Agricultura (Brazilian Agriculture Ministry). Thus, no agrochemicals were used to control plant diseases, although different biological agents and mixtures such as Bordeaux and lime-sulfur could be used. With regard to the use of corrective amendments and fertilizers of industrial origin, only those allowed in the regulations contained in the normative instruction mentioned above were utilized; no synthetic fertilizers were used.

The experiment area had been previously cultivated with sugarcane for four years. The area was tilled by means of one plowing and two harrowings, with incorporation of plant residues. Lime was applied in the entire area, in addition to Thermophosphate as a source of phosphorus and micronutrients. Organic fertilization consisted of 30 litters per pit ( $10 \mathrm{t} \mathrm{ha}^{-1}$ dry matter) rotted cattle manure; $1 / 3$ were placed in the bottom of the pit and $2 / 3$ were homogeneized with dirt and returned to the pit, with the horizons inverted. The initial fertilization for orchard formation was performed by broadcasting the fertilizers on a circle with a $50 \mathrm{~cm}$ radius; applications consisted of $4.5 \mathrm{~kg}$ bird manure per plant, $250 \mathrm{~g}$ Thermophosphate per plant $\left(68 \mathrm{~kg} \mathrm{ha}^{-1} \mathrm{P}\right)$, and $1.2 \mathrm{~kg}$ timber ash per plant $\left(83 \mathrm{~kg} \mathrm{ha}^{-1} \mathrm{~K}\right)$. Bordeaux mixture was applied on the surface and inside the fig tree crowns in order to control plant rust.

Siratro was planted five days after the fig trees were planted, at a density of 30 seeds $\mathrm{m}^{-1}$, distributed in furrows spaced at $0.5 \mathrm{~m}$; bahiagrass was planted as seedlings at a row spacing of $0.3 \times 0.3 \mathrm{~m}$. The mulch was obtained by mowing the turf in areas of the Federal Ru- ral University of Rio de Janeiro campus and of Embrapa Agrobiologia. In 2001, the addition of residues represented by mulch was $25 \mathrm{t} \mathrm{ha}^{-1}$ in February and $32 \mathrm{t} \mathrm{ha}^{-1}$ in August, in order to constantly maintain a layer of at least $0.2 \mathrm{~m}$ in height. Bahiagrass was maintained under a cutting management performed by means of hoeings, at a height of approximately $0.05 \mathrm{~m}$ from the surface, at intervals of ca. 60 days. Siratro management consisted of one cutting in the beginning of 2000 and another in October 2001. The climate data in the study region for the year 2001 are presented in Figure 1. These data were provided by the "Ecologia Agrícola" (Agricultural Ecology) Weather Station of Pesagro-Rio/INMET, located at $\mathrm{km} 47$ in the former Rio-São Paulo Road $\left(22^{\circ} 45^{\prime} \mathrm{S}\right.$ and $43^{\circ} 41^{\prime} \mathrm{O}$, at an altitude of 33 meters), in Seropédica/RJ, Brazil.

The experimental design was organized as random blocks, in a $3 \times 2 \times 2$ factorial scheme, with three replicates. The three treatments consisted of bahiagrass (Paspalum notatum) living mulch (perennial grass with a rhizomatous habit); siratro (Macroptilium atropurpureum) living mulch (herbaceous perennial legume with a voluble habit); and mulch consisting of bahiagrass straw. The macrofauna and plant covers were evaluated in two seasons: March and September 2001, representing the rainy and dry seasons, respectively.

The TSBF (Tropical Soil Biology and Fertility) method, described by Anderson \& Ingram (1993), was used to sample the soil macrofauna. Three samplings were performed at each plot of the experiment area, totaling nine sampling points. A $0.25 \times 0.25 \mathrm{~m}$ area was delimited at each point, and layers of plant material and soil were sampled down to a depth of $0.3 \mathrm{~m}$.

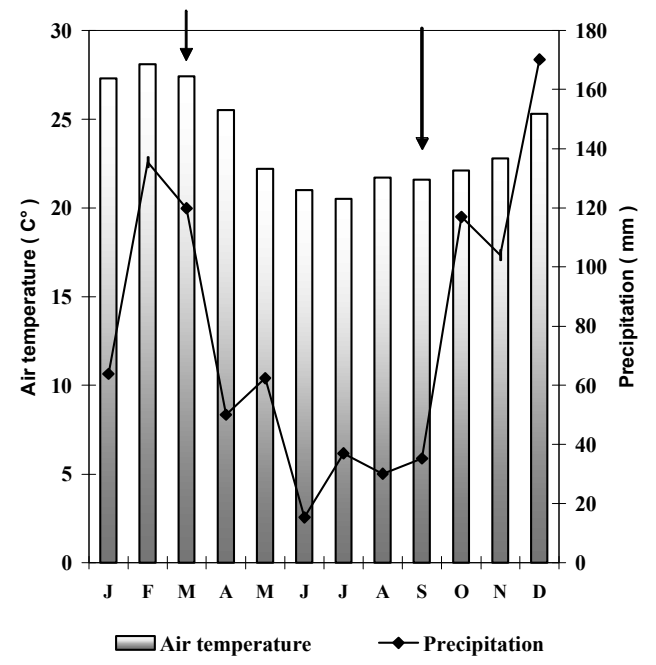

Figure 1 - Air temperature $\left({ }^{\circ} \mathrm{C}\right)$ and precipitation $(\mathrm{mm})$ for the year 2001. Arrows indicate the months when soil macrofauna samplings were taken. 
The macrofauna individuals longer than $10 \mathrm{~mm}$ were removed manually and stored in containers with $70 \%$ alcohol. These were later counted and identified under a stereoscopic microscope, at the level of major taxonomic group. The term group was used in the soil macrofauna study, meaning either a family, or a class or order, with the objective of comprising a set of individuals with a similar life form.

The communities were characterized based on the following parameters: a) density, number of individuals per square meter; b) Shannon Diversity Index $(\mathrm{H})$, calculated by the formula: $\mathrm{H}=-$ " pi.log pi; where pi $=$ ni/ $\mathrm{N}$; ni = density of each group, $\mathrm{N}=$ " of densities of all groups (Magurran, 1988).

The plant layer sampled in both seasons was chemically analyzed according to the method recommended by Bataglia et al. (1983) for N, P, and K determination, and was analyzed for $\mathrm{Ca}$ and $\mathrm{Mg}$ according to Claessen et al. (1997). The results are presented in Table 1.

The chemical characterization of the soil was performed during the March 2001 collection, according to Claessen et al. (1997). Soil moisture was determined in both collection seasons (March - $\mathrm{M}_{\mathrm{i}}$ and September - $\mathrm{M}_{\mathrm{f}}$ ). The results are presented in Table 2 .

The results were submitted to analysis of variance (ANOVA) using the $\mathrm{SAS}^{\circledR}$ (Statistical Analysis System) software. Tukey test was employed to make comparisons between means, at a 5\%. Significant interactions were partitioned according to the factors involved, for treatments, seasons, and depths, whenever significance was found.

Table 1 - Nutrient contents of living mulch and senescent materials of siratro (S) and bahiagrass (B), and mulch (bahiagrass straw) (M). Means of two sampling seasons (March and September, 2001).

\begin{tabular}{lcccc}
\hline Plant cover & $\mathrm{Ca}$ & $\mathrm{Mg}$ & $\mathrm{P}$ & $\mathrm{K}$ \\
\hline & $-17.2 \mathrm{a}$ & $4.0 \mathrm{a}$ & $1.4 \mathrm{ab}$ & $13.3 \mathrm{a}$ \\
$\mathrm{S}$ & $4.6 \mathrm{~b}$ & $2.2 \mathrm{a}$ & $0.9 \mathrm{~b}$ & $4.7 \mathrm{~b}$ \\
$\mathrm{~B}$ & $8.1 \mathrm{ab}$ & $4.6 \mathrm{a}$ & $1.5 \mathrm{a}$ & $10.7 \mathrm{ab}$ \\
\hline $\mathrm{M}$ &
\end{tabular}

Values followed by the same letter do not differ at $5 \%$ (Tukey test).

\section{RESULTS AND DISCUSSION}

\section{Soil macrofauna density}

The soil macrofauna groups Chilopoda, Oligochaeta, and Formicidae were found at higher densities in the soil (Figure 2). Araneae, however, showed a higher density in the plant layer.

Coleoptera, Diplopoda, and Oligochaeta were the most sensitive groups in relation to the season when evaluations were performed, and were more abundant in March (Table 3). Ant density in bahiagrass was similar to ant density in siratro (Table 3). Relatively to all other groups found, ants represented more than $80 \%$ of the macrofauna in bahiagrass, $58 \%$ in siratro, and $8 \%$ in mulch. It is possible that the low nutritional quality of the bahiagrass living mulch (Table 1) did not favor the abundance of other groups. On the other hand, ants, have a wide number of species that become adapted depending on the conditions of the environment (Fowler, 1998), which make them capable of maintaining their reproductive capacity, even when the environmental conditions are unfavorable (Bruyn, 1999). This wide occurrence, in association with the role they play in the soil make ants important, especially in agroecosystems under organic man-

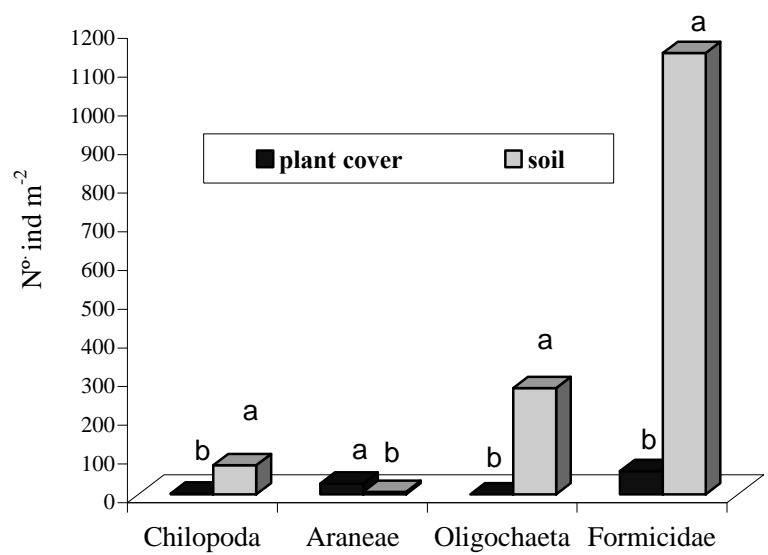

Figure 2 - Soil macrofauna density in plant layers and in soil cultivated with fig trees. (Values refer to means of sampling seasons and different plant cover types). For statistical analysis, values were transformed to $\log x+1$. The same letters in each group do not differ at $5 \%$ (Tukey test).

Table 2 - Chemical characteristics of a Red-Yellow Argisol at a 0-0.3 m depth, under three soil covers ( $\mathrm{S}=$ siratro, $\mathrm{B}=$ bahiagrass, and $\mathrm{M}=$ mulch).

\begin{tabular}{|c|c|c|c|c|c|c|c|c|c|}
\hline Treatment & $\mathrm{pH}_{\mathrm{H} 2 \mathrm{O}}$ & $\mathrm{M}_{(\mathrm{i})}$ & $\mathbf{M}_{(\mathrm{f})}$ & $\mathrm{Al}$ & $\mathrm{Ca}+\mathrm{Mg}$ & $\mathrm{Ca}$ & $\mathrm{Mg}$ & $\mathrm{P}$ & $\mathrm{K}$ \\
\hline & & \multicolumn{2}{|c|}{$-\ldots-1 \%-\ldots$} & \multicolumn{4}{|c|}{ - mmolc $\mathrm{dm}^{-3}-1$} & \multicolumn{2}{|c|}{$\ldots \mathrm{mg} \mathrm{dm}^{-3} \ldots$} \\
\hline S & 5.9 a & $16 \mathrm{a}$ & 15 a & $0.0 \mathrm{a}$ & $4.6 \mathrm{~b}$ & $3.2 \mathrm{a}$ & $1.4 \mathrm{a}$ & $57 \mathrm{a}$ & $128 \mathrm{~b}$ \\
\hline B & $6.1 \mathrm{a}$ & $14 \mathrm{~b}$ & $10 \mathrm{~b}$ & $0.0 \mathrm{a}$ & $4.5 \mathrm{~b}$ & $3.9 \mathrm{a}$ & $1.1 \mathrm{a}$ & $68 \mathrm{a}$ & $104 \mathrm{~b}$ \\
\hline M & $5.9 \mathrm{a}$ & $17 \mathrm{a}$ & $14 \mathrm{a}$ & $0.0 \mathrm{a}$ & $5.3 \mathrm{a}$ & $3.4 \mathrm{a}$ & $1.9 \mathrm{a}$ & 39 a & 368 a \\
\hline
\end{tabular}

These values refer to March 2001, except for $\mathrm{M}_{\mathrm{i}}$ and $\mathrm{M}_{\mathrm{f}}$, which refer to soil moisture measured in March and September 2001, respectively. Values followed by the same letter in the same column do not differ at $5 \%$ (Tukey test). 
Table 3 - Density of individuals in the soil macrofauna in a fig orchard area under different soil covers. (Mean values in the surface layers and in the soil).

\begin{tabular}{|c|c|c|c|c|c|}
\hline Invertebrate groups & Evaluation seasons & Siratro & Bahiagrass & Mulch & Mean \\
\hline & & \multicolumn{4}{|c|}{ - No. ind $\mathrm{m}^{-2} \ldots$} \\
\hline \multirow[t]{3}{*}{ Coleoptera } & $\operatorname{March}^{1,2}$ & 45 & 16 & 72 & $44 \mathrm{a}$ \\
\hline & September & 14 & 3 & 0 & $05 \mathrm{~b}$ \\
\hline & mean & $29 \mathrm{AB}$ & $9 \mathrm{~B}$ & $36 \mathrm{~A}$ & \\
\hline \multirow[t]{3}{*}{ Diplopoda } & March & 251 & 32 & 317 & $200 \mathrm{a}$ \\
\hline & September & 112 & 37 & 29 & $59 \mathrm{~b}$ \\
\hline & mean & $181 \mathrm{~A}$ & $35 \mathrm{~B}$ & $173 \mathrm{~A}$ & \\
\hline \multirow[t]{3}{*}{ Gastropoda } & March & 25 & 6 & 0 & $10 \mathrm{a}$ \\
\hline & September & 75 & 6 & 27 & $36 \mathrm{a}$ \\
\hline & mean & $50 \mathrm{~A}$ & $6 \mathrm{~B}$ & $13 \mathrm{~B}$ & \\
\hline \multirow[t]{3}{*}{ Oligochaeta } & March & 222 & 131 & 237 & $196 \mathrm{a}$ \\
\hline & September & 139 & 75 & 24 & $79 \mathrm{~b}$ \\
\hline & mean & $180 \mathrm{~A}$ & $103 \mathrm{~B}$ & $131 \mathrm{AB}$ & \\
\hline \multirow[t]{3}{*}{ Formicidae } & March & 227 & 1323 & 16 & $522 \mathrm{a}$ \\
\hline & September & 1024 & 968 & 45 & $679 a$ \\
\hline & mean & $625 \mathrm{~A}$ & $1145 \mathrm{~A}$ & $31 \mathrm{~B}$ & \\
\hline
\end{tabular}

${ }^{1}$ For statistical analysis, values were transformed to $\log x+1$.

${ }^{2}$ The same upper case letters in the same row or lower case letters in the same column do not differ at $5 \%$ ( Tukey test).

agement, where the work they perform in biological processes is more expressive than the damage threat they pose to crops.

The ant genera found were: Crematogaster, Brachymyrmex (which occurred especially in bahiagrass), Solenopsis, Pheidole, Hypoponera (especially in siratro), and Mycocepurus. This provides an indication of the relevance of this group to the soil fauna community, since it presents great diversity and becomes established in several habitats. When abundant, ants can modify the soil's physical structure by creating systems of galleries and chambers, influencing soil porosity, aeration, infiltration, and drainage (Lavelle \& Spain, 2001). They also change soil texture and other soil properties through the horizontal and vertical transfer of materials of different particle sizes (Alvarado et al., 1981).

When both living mulches are compared, a higher density of Oligochaeta, Diplopoda, and Gastropoda can be found in the siratro living mulch than in bahiagrass (Table 3). Since Oligochaeta and Diplopoda are saprophytic, the higher density observed is probably associated with the greater food supply, organic matter quality, and higher soil moisture (Tables 1 and 2). Gastropods depend on calcium to build their shells, which represent a protection for their bodies (Burch \& Pearce, 1990). This was probably a decisive factor why the siratro vegetation influenced the distribution of this group (Table 2).

In the mulch treatment, incorporation of residues amounted to $25 \mathrm{t} \mathrm{ha}^{-1}$ in February and $32 \mathrm{t} \mathrm{ha}^{-1}$ in August. With regard to the living mulches, the production of siratro and bahiagrass residues was not quantified, but results obtained under similar edaphic-climatic conditions showed that bahiagrass yields about $4,000 \mathrm{~kg} \mathrm{ha}^{-1}$ in summer and $1,600 \mathrm{~kg} \mathrm{ha}^{-1}$ in the beginning of spring (Espíndola et al., 2001), and that siratro yields $3,100 \mathrm{~kg}$ $\mathrm{ha}^{-1}$ when harvested in the dry season and 3,700 kg ha when harvested in the rainy season (Espíndola, 2001). However, evaluations performed in the experiment area of the fig orchard have shown that siratro presents substantial spontaneous leaf shedding, which represented around $1.45 \mathrm{t} \mathrm{ha}^{-1}$ dry matter per month throughout 2002 (personal comm.).

Mulch cover increases earthworm populations in the soil, as compared with bare soil, and this effect is positively correlated with the quality of the mulch (Tian et al. 1999) although these factors are determinative for the occurrence of earthworms (Edwards \& Lofty, 1982; Lee, 1985), exclusive colonization by Pontoscolex corethrurus (Muller) was observed, and no native species were found, such as those reported by Aquino (1999) to occur in a nearby secondary vegetation area.

Araneae and Chilopoda predators were found in all soil covers at low densities. These groups are related to more diversified habitats (Altieri et al., 1996; Odum, 1988).

\section{Soil macrofauna diversity}

Diversity determination is highly important because it can function as a bioindicator of community stability and describe the ecological dynamics of the commu- 


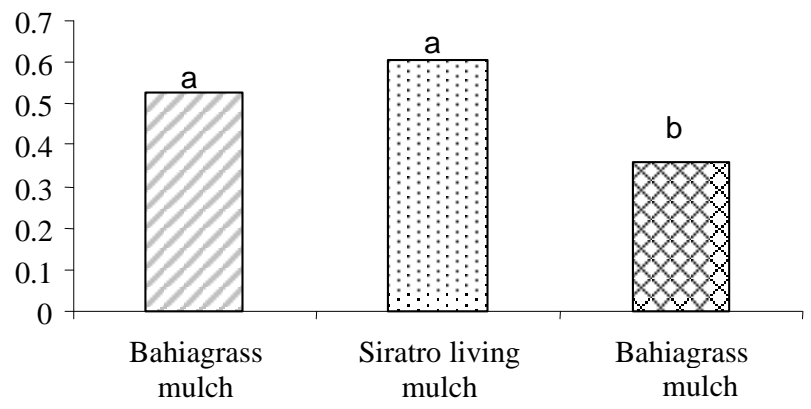

Figure 3 - Soil macrofauna diversity (Shannon index) in a fig orchard area under different soil covers (values refer to the mean between two sampling seasons). Same letters do not differ $5 \%$ (Tukey test).

nity and the impact of stress (Kennedy \& Smith, 1995). No difference of Shannon index was detected between evaluation seasons (March and September). Therefore, the data presented refer to the mean of these collections in each treatment. Shannon index, which refers to both richness and density, was similar for mulch and siratro (Figure 3 ).

In spite of the high macrofauna density found in the bahiagrass treatment (1,306 individuals $\left.\mathrm{m}^{-2}\right)$, the Shannon index was lower in this treatment in relation to the mulch and siratro treatments (Figure 3 ). The diversity values found in this experiment can be considered high, when compared to those found in other areas cultivated under the conventional system and under no-till, and are very close to the values found in forest soils (Aquino et al., 2000).

\section{CONCLUSIONS}

Using the soil macrofauna community as a whole worked better as a bioindicator than if a certain group from the fauna would have been selected for that purpose.

The macrofauna density and diversity indicated that the living mulch with bahiagrass encourages a more stressing and impacting environment for the community than soil covers consisting of siratro living mulch or bahiagrass straw mulch.

\section{REFERENCES}

ALMEIDA, D.L. de; RIBEIRO, R. de L.D.; GUERRA, J.G.M. Sistema Integrado de Produção Agroecológica ("Fazendinha Agroecológica km 47”). In: SIMPÓSIO DE AGRICULTURA ECOLÓGICA, 2., ENCONTRO DE AGRICULTURA ECOLÓGICA, 1., São Paulo, 1999. Agricultura ecológica. Guaíba: Livraria e Editora Agropecuária Ltda., 1999. v.2, p.152-159.

ALTIERI, M.A.; NICHOLLS, C.I.; WOLFE, M.S. Biodiversity - A central concept in organic agriculture: pest and diseases. In: INTERNATION SCIENTIFIC CONFERENCE, 11., Copenhagen. Proceedings. Copenhagen: IFOAM, 1996. p.11-15.

ALVARADO, A., BERISH, C.W.; PERALTA, F. Leaf-cutter ant (Atta Cephalotes) influence on the morphology of Andepts in Costa Rica. Soil Science Society of America Journal, v.45, p.790-794, 1981.

ANDERSON, J.D.; INGRAM, J.S.I. Tropical soil biology and fertility: a handbook of methods. 2.ed. Wallingford: CAB International, 1993. 171p.
AQUINO, A.M. Meso- e macrofauna do solo e sustentabilidade agricola: perspectivas e desafios para o seculo XXI. In: CONGRESSO BRASILEIRO DE CIENCIA DO SOLO, 27., Brasília, 1999. Palestras. Brasília: SBCS, 1999. 504b.

AQUINO, A.M.; MERLIM, A.O.; CORREIA, M.E.F.; MERCANTE, F.M. Diversidade da macrofauna do solo como indicadora de sistemas de plantio direto para a região oeste do Brasil (compact disk). In: REUNIÃO BRASILEIRA DE FERTILIDADE DO SOLO E NUTRIÇÃO DE PLANTAS, 24.; REUNIÃO BRASILEIRA SOBRE MICORRIZAS, 8.; SIMPÓSIO BRASILEIRO DE MICROBIOLOGIA DO SOLO, 6.; REUNIÃO BRASILEIRA DE BIOLOGIA DO SOLO, $\mathrm{n}^{\circ} 3$, Santa Maria, 2000. Biodinâmica do solo. Santa Maria: SBCS; SBM, 2000. FERTBIO 2000.

BATAGLIA, O.C.; FURLANI, A.M.C.; TEIXEIRA, J.P.F.; GALO, J.R. Métodos de análise química de plantas. Campinas: Instituto Agronômico, 1983. 48p. (Boletim, 78).

BRUYN, L.A. Ants as bioindicators of soil function in rural environments. Agriculture, Ecosystems and Environment., v.74, p.425-441, 1999.

BURCH, J.B.; PEARCE, T.A. Terrestrial gastropoda. In: DINDAL, D.L. (Ed.) Soil biology guide. New York: John Wiley, 1990. p.201-309.

CLAESSEN, M.E.C.; BARRETO, W. de O.; PAULA, J.L. de; DUARTE, M.N. Manual de métodos de análise de solo. 2.ed. Rio de Janeiro EMBRAPA, CNPS, 1997. 212p. (Documentos 1).

COSTA, P. Fauna do solo em plantios experimentais de Eucalyptus grandis Maiden, Pseudosamanea guachapele Dugand e Acacia mangium Willd. Seropédica: UFRRJ, 2002. 93p. (Dissertação - Mestrado).

EDWARDS, C.A.; LOFTY, J.R. The effect of direct drilling and minimal cultivation on earthworm populations. Journal of Applied Ecology, v.19, p.723-734, 1982.

ESPÍNDOLA, J.A.A. Avaliação de leguminosas herbáceas perenes usadas como cobertura viva do solo e sua influência sobre a produção da bananeira (Musa spp.) Seropédica: UFRRJ, 2001. 144p. (Tese Doutorado).

ESPÍNDOLA, J.A.A.; ALMEIDA, D.L.DE; GUERRA, J.G.M.; SILVA E.M.R.DA. Flutuação sazonal da biomassa microbiana e teores de nitrato e amônio de solo coberto com Paspalum notatum em um agroecossistema. Floresta e Ambiente, v.8, p.104-113, 2001.

FOWLER, H.G. Ecologia, formigas indicam nível de recuperação de áreas degradadas pela mineração. Ciência Hoje, v.4, p.69-71, 1998.

KENNEDY, A.C.; SMITH, K.L. Microbial diversity and the sustainability of agricultural soils. Plant and Soil, v.170, p.75-86, 1995.

LAVELLE, P. Soil function in a changing world: the role of invertebrate ecosystem engineers. European Journal of Soil Biology, v.33, p.159193, 1997.

LAVELLE, P.; BLANCHART, E.; MARTIN, A.; SPAIN, A.; TOUTAIN, F.; BAROIS, I.; SCHAEFER, R. A hierarchical model for decomposition in terrestrial ecosystems: applications to soils of the humid tropics. Biotropica, v.25, p.130-150, 1993.

LAVELLE, P.; SPAIN, AV. Soil ecology. Dordrecht: Kluwer Academic Publishers, 2001. 654p.

LEE, K.E. Earthworms their ecology and relationships with soils and land use. Canberra: Academic, 1985.

MAGURRAN, A.E. Ecological diversity and its measurement. New Jersey: Princeton University, 1988. 177p.

ODUM, E.P. Ecologia. Rio de Janeiro:Guanabara, 1988. 434p.

PANKRURST, C.E.; LYNCH, J.M. The role of the soil biota in sustainable agriculture. In: PANKRURST, C.E.; DOUDE, B.M.; GUPT, V.V.S.R.; GRACE, P.R. (Ed.) Soil biota: Management in sustainable farming systems. Camberra: CSIRO, 1994. 262p.

SWIFT, M.J.; HEAL, O.W.; ANDERSON, J.M. Decomposition in terrestrial ecosystems. Berkeley: University of California, 1979. 372p

TIAN, G.; BRUSSARD, L.; KANG, B.T. The role of plant residue with different chemical compositions in sustaining maize production in a subhumid tropical enviroment. In: BADEJO, M.A.; TOGUN, A.O. (Ed.). Strategies and tactics of sustainable agriculture in the tropics. Ibadan: College Press; Surulere: Emproct Consultants, 1999. v.1, p.68-84.

VAN STRAALEN, A. The detritus food-web and the diversity of soil fauna as indicators of disturbance regimes in agro-ecosystems. Plant and Soil, v.170, p.35-43, 1998.

$\overline{\text { Received April 04, }} 2004$

Accepted December 01, 2004 